\title{
Transport factor and types of settlement development in the suburban area of the Moscow capital region
}

\author{
Petr Krylov ${ }^{1, *}$ \\ ${ }^{1}$ Moscow Region State University, 105005, Radio str, 10A, Moscow, Russia
}

\begin{abstract}
The paper considers the ratio of the transport factor and the types of development of settlements in the suburban area of the Moscow capital region. The purpose of this research is to study the specific features of the development of settlements in various radial directions from the node (core) of Moscow capital region - the Moscow city. Data from publicly available electronic maps were used, including data from the public cadastral map. Historical and socio-economic prerequisites for the formation of various types of development along radial transport axes (public roads of regional and federal significance connecting Moscow with the territory of the Moscow region and other regions of Russia) are considered. Conclusions about the general and specific features of development along different directions at different distances from Moscow are drawn. The research confirms the hypothesis that the ratio of certain types of residential development along various highways differs from place to place depending on the time of the origin of the transport routes themselves, on the economically determined choice of investors, and in recent years - on the environmentally determined choice of the population.
\end{abstract}

\section{Introduction}

The transport factor is one of the most important for the formation of the settlement system both through the level of transport development of the territory, and taking into account the variety of forms of transport accessibility and connectivity of spatial elements of the territory. According to S.A. Tarkhov, the near Moscow region and its Eastern sector fall under the definition of "area of continuous development of the territory" [1]. However, the current level of development of the territory was formed over a long historical period. During several centuries and decades of the XX century, there are several forms and stages of formation and development of suburban areas of large cities [1, 2].

\section{Materials and methods of the research}

For the basis of this research, we used data from the public cadastral map for the territory of the Moscow region, as well as various auxiliary electronic maps (including the "Yandex -

* Corresponding author: pmkrylov@yandex.ru 
maps" service (https://yandex.com/maps/), as well as information from the public cadastral map (https://pkk.rosreestr.ru/)). The purpose of this research is to study the specific features of the development of settlements in various radial directions from the node (core) Moscow capital region - the Moscow city.

However, it should be noted that this type of transport gravity currently has a more complex structure. In addition to the estimated (conditional) time to reach the destination, the real, actual time, adjusted for unpredictable traffic delays due to "traffic jams" and other little-predicted factors of increasing the length of traffic time began to play an increasing role. Therefore, if we are talking about the need to get to a strictly defined time to the place of work, many owners of private vehicles assess the transport accessibility from the place of residence to the place of employment with a large margin in case of delays, especially during "rush hours", or proceed with a combined (integrated) method of movement: use the nearest "intercept parking" and, having reached them, leave their personal vehicles there, and then use public, mainly railway transport.

In many domestic and foreign studies, the ratio of the role of the transport factor in the dynamics of settlement at the level of development types is practically not considered $[3,4$, $5,6]$.

The choice of railway transport is associated with greater accuracy of its movement, that is greater predictability of arrival at the final point of the route. Public road transport (buses, including low-capacity buses, etc.) is much less predictable from this point of view.

The most recent changes in the transport system of the capital region are also acting in this direction: the appearance in 2019 of the first two "Central diameters", which are actually analogous to the metro, but with its removal beyond the administrative borders of Moscow.

\section{The results and discussion of the research}

The impact of the development of extra-urban transport on settlement in the Eastern sector of the Moscow region can be divided into the following periods: 1) the river (before the development of horse-drawn transportation in the late $18^{\text {th }}$ - early $19^{\text {th }}$ centuries;

2) horse-drawn and river (increase in the share and role of horse-drawn transport with a slight decline of river transportation);

3) railway-water (gradual increase in the value of railway transport in reducing the role and share of horse-drawn and river transport (the second half of the $19^{\text {th }}$ century and early $20^{\text {th }}$ century));

4) railway and road (the prevailing importance of suburban railway transport with a slow increase in road transport due to the growth of the length and quality of public roads (mid - late $20^{\text {th }}$ century));

5) road-railway (increasing the value of road transport, including bus transport, while decreasing the value of railway transport (end of $20^{\text {th }}$ century - present time).

Until the middle of the XIX century, the main cities - industrial and craft centers, as well as most rural localities existed near the Moscow river and Klyazma, or on inter-flood plains on the most fertile soils.

Starting since 1862, the first sections of the Moscow-Ryazan railway were put into operation. Most of it ran away from previously developed agricultural land and did not always coincide with the main directions of horse-drawn roads of that time. This has contributed to the emergence of new residential settlements, as well as suburban settlements (at a distance of 35-45 km from the main railway station in Moscow), surrounded by pine forests and far from the main areas of agricultural land. The operation of the railway facilitated the redistribution of goods from previously uncontested horse-drawn roads and river routes. 
One of the largest in its economic significance and the number of permanent population is the ancient city of Bronnitsy (Moscow region) gradually lost its significance, as the railway passed at a distance of more than ten kilometers from the city.

The emergence and growth of "mass Soviet summer houses" in the 1970s and 1980s was largely limited by the availability of suburban rail and bus transport.

The last 30 years (1990-2020), as in all other regions of Russia, there has been a significant increase in motorization of the population in the Moscow capital region. This contributed to the emergence of cottage settlements, new summer houses cooperatives, including horticultural non-profit associations (HNA) in places with previously relatively poor transport accessibility by public transport. Highways have become new corridors axes of development. Located along highways with increasing traffic flows, old villages and countries have received another development due to the activation of roadside trade and the provision of a wide range of various services.

The growth of the population of the city of Lyubertsy (Moscow region) is predetermined by the direct proximity of its territory to Moscow. The transport factor determined the rapid growth of Moscow's borders in the $20^{\text {th }}$ century and the actual (but not always legal) joining of adjacent towns and villages to the capital.

The trend of the last decade is a significant growth and consolidation of development along the main roads and railways of public use, allowing to reach Moscow or other cities of the Moscow capital region with minimal time costs.

However, adjacent to the largest traffic flows on highways and railways of the territory are not and cannot in principle be places of comfortable living at the present time due to the inability to completely overcome noise and atmospheric pollution, worsening the quality of life and reduce the market (but not always cadastral) value of land plots.

According to experts, the maximum negative environmental effect of major highways extends to 30-50 meters on both sides of the highway, and noise protective screens only slightly reduce noise pollution, but practically do not affect the pollution of the atmosphere.

In addition, as shown by a number of studies [7, 8, 9, 10], in our country, the environmental factor in the form of the negative impact of large traffic flows on the surrounding area is increasingly recognized by the population and negatively affects their choice when buying (renting, etc.) land or housing. This, in turn, affects the real estate market and, ultimately, leads to the development (or curtailment) of new housing construction in certain locations relative to highways.

The opposite effect is also evident - the negative impact of existing residential development of territories adjacent to transport highways. The larger it is, the less likely it is that private companies (including in the form of public-private partnerships) will invest in the construction of new, bypass or expressways that are so necessary for the capital region. It is becoming more and more difficult and expensive to find vacant land for new transport corridors, as it is too expensive for both state authorities and municipalities, and especially for private investors, to move out of existing residential buildings and buy out settlement land.

Taking into account the changing over time the role of the transport factor in the territory of the South-East of the Moscow region in the suburban area of the capital region, we have identified the following types of settlements:

1. Old agricultural rural settlements that arose historically based on the use of land, forest or water resources as means of production.

Today, many of them are separated by highways that run through their streets, and the first line of households on both sides of the highways is gradually being replaced by nonresidential (service) buildings and services. 
2. Settlements with historical estates, which previously had an important cultural and educational role, performed the function of managing a large rural and sometimes industrial economy.

Historical estates in the Moscow region are currently either being destroyed, or becoming tourist or resort and sanatorium facilities. If they are located within the boundaries of rural settlements, estates have a certain influence on them and can serve not only as "historical heritage of a protected type", but also as a potential factor of development, distinguishing these settlements from others.

3. Summer houses (suburban) settlements of the end of the XIX century, mainly in the forest area and near reservoirs, sometimes - according to Chekhov - on the site of felled "The Cherry Orchards" in landowners' estates, initially near the railways.

4. Summer houses (suburban) settlements of Soviet officials of the 30s of the XX century, sometimes of workers, on the site of former pre-revolutionary summer houses. With a sharp change of owners, the functions of settlements remained similar.

5. Workers' settlements with multistory (up to 5 floors) houses with centralized communications and a minimum of social facilities that appeared during the years of industrialization are not very far from the railways. Such workers' settlements usually have informal names ("Electroposelok", "Metrostroy", "Gosstatistika", etc.) after the name of the main enterprise or organization in Moscow.

Over the past 50-70 years, villages have become the core of urban life as part of suburban and rural areas. Their improvement after being transferred to the municipal authorities from enterprises is currently a big problem for the Moscow region.

6. Dense low-rise private development with year-round residence, but with poor landscaping, with houses for several owners and very small land plots, partially replaced suburban development after 1945 and located on the first lines of the railway, near railway stations.

7. Rich, often two - and three-story, villas, mansions of rich people "new Russian", which appeared after 1991 among the old suburban development, with land plots larger than the standard for most residents of six acres (an area of more than $600 \mathrm{~m}^{2}$ ), located, as a rule, in environmentally relatively more favorable "niches".

8. Large cottage settlements with the right to live all year round and all utilities on allocated relatively large plots of land, mainly on purchased abandoned agricultural land.

In the last 25 years, due to a sharp increase in motorization, there has been a noticeable increase in new development along federal and regional roads, but not near railways.

9. Commercial multistory development or townhouses on small plots of land (point construction) in densely and long ago built suburban settlements - often on the border between two settlements, or in the zones near the railway and local roads, in relatively poor environmental conditions.

10. Former military towns that were most often built in remote rural areas of the region or on the outskirts of cities. They are less integrated into the environment due to a long period of isolation, and have major problems with housing and utilities and employment of former military personnel and their families. The transfer of such military towns to the municipal authority took place later than the transfer of another departmental housing stock, and there are more problems with landscaping in them today. Since 2016 the Moscow region has a Targeted program to modernize more than 60 of 187 such settlements with a population of 152 thousand people.

In order to compare the current situation with the built-up areas of various types of residential development along the main highways, we analyzed six highways located in the Eastern sector of the Moscow capital region, starting from the North of the Moscow region (Dmitrovskoe highway) and to the South - up to the new Kashirskoye highway (table 1). 
Their total length was calculated conditionally from the MKAD (The Moscow Automobile Ring Road) to the so-called "betonka" (Federal highway A107 (Moscow small ring) - a ring highway in the Moscow region, passing through the cities of Noginsk, Elektrostal, Bronnitsy, the territory of the cities and towns of Domodedovo, Selyatino, Zvenigorod, Chernogolovka, Sofrino) with an accuracy of $0.5 \mathrm{~km}$. It is known that in some cases Moscow has already "gone" beyond the MKAD and it would be more correct to start counting from its actual borders (as, for example, in the case of the Ryazanskoye highway). However, the situation with the "starting point" quite difficult - in some areas, Moscow's territory is formally only one side of the highway, while on the other side of highway, officially - it is still the territory of the Moscow region.

Note also that the Yegor'yevskoye highway still has no direct access to the MKAD, and formally begins on the outskirts of Lyubertsy town. We choose for analysis the new Kashirskoye highway due to the fact that it is the only highway in the Eastern sector of Moscow region has already been built in parallel to the old (Kashirskoye) highway (including a hypothetical division of the Moscow region on the Western and Eastern geographical sector). Hypothetically, we assumed that it was laid as far as possible "around" the old (already existing on this route) settlements, and this hypothesis should be confirmed or disproved. The length of a particular type of development: an old rural, multistory commercial, cottage or suburban development, was calculated using the "Yandex - maps" Internet service under viewing information in different modes. This allows to identify a particular type of development with sufficient confidence. Its length was calculated as the average of the sum of the length of the same development on both sides of the highway.

As we can see from table 1, the length of each of the six considered highways from the MKAD to the "betonka" differs slightly, varying in the range from 28 (minimum length) to 41 (maximum length) kilometers, and is on average 33.8 kilometers. However, the length of a particular type of settlement development along them varies significantly.

We used the official names of public roads of Federal significance in table 1: "Betonka": highway A-107 "Moscow small ring" Iksha - Noginsk - Bronnitsy - Golitsyno - Istra - Iksha; Kashirskoe highway: highway M-4 "Don" Moscow - Voronezh - Rostovon-Don - Krasnodar - Novorossiysk; Ryazanskaye highway: highway M-5 "Ural" Moscow - Ryazan - Penza - Samara - Ufa - Chelyabinsk; Gor'kovskoe highway: highway M-7 "Volga" Moscow - Vladimir - Nizhny Novgorod - Kazan - Ufa; Yaroslavskoye highway: highway M-8 "Kholmogory" Moscow - Yaroslavl - Vologda - Arkhangelsk. Official names of public roads of regional and inter-municipal significance: Yegor'yevskoye highway: P-105 highway Moscow - Yegoryevsk - Tuma - Kasimov; Dmitrovskoe highway: highway A-104 Moscow - Dmitrov - Dubna.

Data on multistory commercial development in table 1 are presented with the account of industrial and warehouse development located no further than 300 meters from the highway.

Thus, for Gor'kovskoe highway, a sharp predominance of multistory commercial development $(33.9 \%)$ was revealed, while the other three types of development occupy approximately equal areas in length: $9.0 \%$ (old rural development), 10.3\% (cottage development) and $9.0 \%$ (suburban development). This is due to intensive development in the city district of Balashikha and in other large localities near Moscow.

For Dmitrovskoe highway, the most uniform distribution of various types of development was found: two of them occupy $12.5 \%$ (old rural development and multistory commercial development), and the other two $-7.1 \%$ (cottage development and suburban development).

On the contrary, the most contrasting distribution of the length of various types of development was found for Yaroslavskoye highway: from 1.6\% (old rural development) to 
$40.3 \%$ (multistory commercial development). In addition, it should be noted that it is for this highway that two relative maximum have been identified - in addition to the already mentioned $40.3 \%$ under multistory development, $25.8 \%$ is occupied along it by suburban development. Both of these indicators are the maximum for their type of development in the considered combination, and significantly exceed the average indicators $-21.4 \%$ (within 1.88 times) and $14.8 \%$ (within 1.74 times), respectively. The third relative maximum (for old rural development) was found at the Ryazanskoye highway - $17.1 \%$ (with an average for the combination of $10.3 \%$ ). The excess is 1.66 times.

Much more similar indicators for all six highways were found for the cottage type of development - with an average of $8.1 \%$, for two highways - Gor'kovskoe and Yegor'yevskoye, this indicator is $10.3 \%$ (the maximum indicators for this type of development), or only within 1.3 times more than the average. For the other four highways, this figure is also very close to the average by the combination.

We should also focus on the situation with the new Kashirskoe highway. As mentioned above, this highway is the newest, built in parallel with the old Kashirskoe highway, high speed (without intersections at the same level with other transport routes and without ground pedestrian crossings), while driving on it is paid, unlike the other highways considered in this study.

As can be seen from table 2, the relative length of free, undeveloped space on both sides of this highway is the maximum for the combination under consideration and is $76.7 \%$. The minimum is marked at Yaroslavskoye highway - only a quarter $(25.8 \%)$ of its length is not yet built up, with the average indicator for the combination $-45.3 \%$.

It should be noted in this regard that in modern Russia newly built highways, especially with private or public-private capital, are designed and laid, if possible, bypassing existing localities. This is mainly done in our country not so much for good environmental reasons, but because of the desire of investors to reduce the cost of purchased land, relocation of people, compensation for losses of all types, etc.

As expected at the beginning of the research, the parameters of the length of various types of development along such highways should differ from those of the "old" highways that inherited the historical transport routes that passed through most localities along their length. This is what was revealed in relation to the new Kashirskoe highway. Thus, the length of the old rural and suburban development on it was $6.6 \%$ each (which is lower than the average for the corresponding type of development). For old rural development, this indicator would be minimal relative to the entire sample, if we do not take into account the corresponding indicator identified for Yaroslavskoye highway (1.6\%), which is extremely low and has a different origin. In the latter case, obviously, the reason is the replacement of the old rural development with a new "urban", multistory development, as we have already noted above.

The new Kashirskoe highway was also characterized by a minimum of commercial multistory development (only $1.7 \%$, with an average of $24.4 \%$ in the combination), and a close to average indicator for cottage development - 8.3\%, with an average of $8.1 \%$. At the same time, only for this highway, the length, especially of cottage development (the newest in time of occurrence, along with part of a multistory commercial development) exceeds the share of all other types of development, while for the combination, on average, it is in the last, fourth place (tables 1 and 2). 
Table 1. The length of the type of settlement development along the highway (the average of sum of development on both sides) as of 2019 .

\begin{tabular}{|c|c|c|c|c|c|c|c|c|c|}
\hline \multirow{3}{*}{$\begin{array}{c}\text { Federal highway } \\
\text { or a highway of } \\
\text { regional } \\
\text { significance, } \\
\text { from North to } \\
\text { South }\end{array}$} & \multirow{3}{*}{$\begin{array}{c}\text { The } \\
\text { distance } \\
\text { from } \\
\text { MKAD } \\
\text { to } \\
\text { "betonka" } \\
\text { total, km }\end{array}$} & \multicolumn{8}{|c|}{$\begin{array}{l}\text { The length of the type of settlement development along the } \\
\text { highway (the average of sum of development on both sides) } \\
\text { as of } 2019\end{array}$} \\
\hline & & \multicolumn{2}{|c|}{$\begin{array}{c}\text { Old rural } \\
\text { development }\end{array}$} & \multicolumn{2}{|c|}{$\begin{array}{c}\text { Multistory } \\
\text { commercial } \\
\text { development }\end{array}$} & \multicolumn{2}{|c|}{$\begin{array}{c}\text { Cottage } \\
\text { development }\end{array}$} & \multicolumn{2}{|c|}{$\begin{array}{c}\text { Suburban } \\
\text { development }\end{array}$} \\
\hline & & $\mathbf{k m}$ & $\%$ & $\mathbf{k m}$ & $\%$ & km & $\%$ & $\mathbf{k m}$ & $\%$ \\
\hline $\begin{array}{l}\text { Dmitrovskoe } \\
\text { highway }\end{array}$ & 28.0 & 3.5 & 12.5 & 3.5 & 12.5 & 2.0 & 7.1 & 2.5 & 7.1 \\
\hline $\begin{array}{l}\text { Yaroslavskoye } \\
\text { highway }\end{array}$ & 31.0 & 0.5 & 1.6 & 12.5 & 40.3 & 2.0 & 6.5 & 8.0 & 25.8 \\
\hline $\begin{array}{l}\text { Gor'kovskoe } \\
\text { highway }\end{array}$ & 39.0 & 3.5 & 9.0 & 10.5 & 33.9 & 4.0 & 10.3 & 3.5 & 9.0 \\
\hline $\begin{array}{l}\text { Yegor'yevskoye } \\
\text { highway }\end{array}$ & 34.0 & 4.5 & 13.2 & 7.5 & 22.1 & 3.5 & 10.3 & 7.5 & 22.1 \\
\hline $\begin{array}{l}\text { Ryazanskoye } \\
\text { highway }\end{array}$ & 41.0 & 7.0 & 17.1 & 9.0 & 22.0 & 2.5 & 6.1 & 6.5 & 15.9 \\
\hline $\begin{array}{l}\text { Kashirskoe } \\
\text { highway }\end{array}$ & 30.0 & 2.0 & 6.6 & 0.5 & 1.7 & 2.5 & 8.3 & 2 & 6.6 \\
\hline Total: & 203.0 & 21 & 10.3 & 43.5 & 21.4 & 16.5 & 8.1 & 30 & 14.8 \\
\hline
\end{tabular}

Table 2. Typology of development along highways in the near zone of the Moscow region (the proportion of the length of various types of development relative to the total built-up area).

\begin{tabular}{|c|c|c|c|c|c|c|c|c|}
\hline \multirow{2}{*}{ 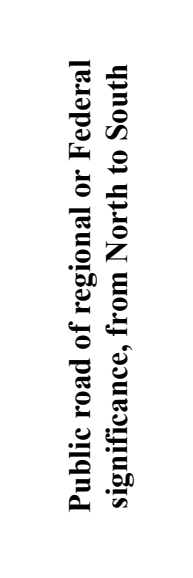 } & \multicolumn{2}{|c|}{ 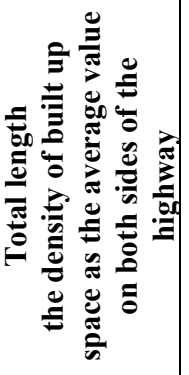 } & \multicolumn{4}{|c|}{$\begin{array}{c}\text { Share } \\
\text { length of various types of development relative to } \\
\text { the total built-up area, } \%, 2019\end{array}$} & \multicolumn{2}{|c|}{ 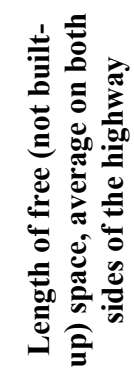 } \\
\hline & km & $\%$ & $\begin{array}{c}\text { Old rural } \\
\text { developme } \\
\text { nt }\end{array}$ & $\begin{array}{c}\text { Multistory } \\
\text { commerci } \\
\text { al } \\
\text { developme } \\
\text { nt }\end{array}$ & $\begin{array}{c}\text { Cottage } \\
\text { developme } \\
\text { nt }\end{array}$ & $\begin{array}{c}\text { Suburban } \\
\text { developme } \\
\text { nt }\end{array}$ & km & $\%$ \\
\hline $\begin{array}{l}\text { Dmitrovskoe } \\
\text { highway }\end{array}$ & 11.5 & $\begin{array}{c}41 . \\
1\end{array}$ & 30.4 & 30.4 & 17.4 & 21.8 & $\begin{array}{c}16 . \\
5\end{array}$ & $\begin{array}{c}58 . \\
9\end{array}$ \\
\hline $\begin{array}{l}\text { Yaroslavskoy } \\
\text { e highway }\end{array}$ & 23.0 & $\begin{array}{c}74 . \\
2 \\
\end{array}$ & 2.2 & 54.3 & 8.7 & 34.8 & 8.0 & $\begin{array}{c}25 . \\
8\end{array}$ \\
\hline $\begin{array}{l}\text { Gor'kovskoe } \\
\text { highway }\end{array}$ & 21.5 & $\begin{array}{c}55 . \\
1\end{array}$ & 16.3 & 48.8 & 18.6 & 16.3 & $\begin{array}{c}17 . \\
5\end{array}$ & $\begin{array}{c}44 . \\
9\end{array}$ \\
\hline $\begin{array}{l}\text { Yegor'yevsk } \\
\text { oye highway }\end{array}$ & 23.0 & $\begin{array}{c}67 . \\
6 \\
\end{array}$ & 19.6 & 32.6 & 15.2 & 32.6 & $\begin{array}{c}11 . \\
0\end{array}$ & $\begin{array}{c}32 . \\
4 \\
\end{array}$ \\
\hline $\begin{array}{l}\text { Ryazanskoye } \\
\text { highway }\end{array}$ & 25.0 & $\begin{array}{c}61 . \\
0\end{array}$ & 28.0 & 36.0 & 10.0 & 26.0 & $\begin{array}{c}16 . \\
0\end{array}$ & $\begin{array}{c}39 . \\
0\end{array}$ \\
\hline $\begin{array}{l}\text { Kashirskoe } \\
\text { highway }\end{array}$ & 7.0 & $\begin{array}{c}23 . \\
3\end{array}$ & 28.6 & 7.1 & 35.7 & 28.6 & $\begin{array}{c}23 . \\
0\end{array}$ & $\begin{array}{c}76 . \\
7\end{array}$ \\
\hline Total: & $\begin{array}{c}111 . \\
0\end{array}$ & $\begin{array}{c}54 . \\
7\end{array}$ & 18.9 & 39.2 & 14.9 & 27.0 & $\begin{array}{c}92 . \\
0\end{array}$ & $\begin{array}{c}45 . \\
3\end{array}$ \\
\hline
\end{tabular}




\section{Conclusions}

According to the combination of factors of transport accessibility and environmental friendliness, it is obvious that we can distinguish the most expensive territories by market value, which have the possibility to choose external transport links both by road and by rail. These include, in particular, the so-called "old summer houses" localities, for example, a continuous series of settlements from the village of Tomilino to the village of Kratovo along the Moscow-Ryazan direction of the Moscow railway.

The discussed above seems to confirm the hypothesis that the ratio of certain types of settlement development along various highways differs from place to place depending on the time of the origin of the transport routes themselves, on the economically determined choice of investors, and in recent years - on the environmentally determined choice of the population.

\section{References}

1. S.A. Tarkhov, MSU Bulletin. Series 5. Geography 2, 3 (2018)

2. V.D. Oleinik, A.V. Gladkiy, Pskov regionological journal 1(25), 31 (2016)

3. Jean-Paul Rodrigue, The Geography of Transport Systems Fifth Edition (New York, Routledge, 2020)

4. Maria Merki Christoph, Verkehrsgeschichte und Mobilität (Stuttgart, Utb Profile, 2008)

5. Helmut Nuhn, Markus Hesse, Verkehrsgeographie (Stuttgart, Utb Profile, 2006)

6. M.D. Meyer, Transportation Planning Handbook. 4th Edition (New York, Kindle Edition, ITE, 2016)

7. I.S. Voronezhtsev, VSU Bulletin. Series: Geography. Geoecology 2, 65 (2013)

8. G.A. Pivovar, A.I. Alekseev, MSU Bulletin. Series 5. Geography 6, 100 (2018)

9. P.V. Tarasenko, N.P. Ermolaeva, Collection: Environmental, legal and economic aspects of rational use of land resources. Collection of articles of the II International scientific and practical conference dedicated to the year of ecology in Russia (2017)

10. A. Mottaeva, E3S Web of Conferences 110, 02164 (2019) doi.org/10.1051/e3sconf /201911002164

11. E.N. Bykova, Y.I. Sapozhnikova, Collection: Agricultural science-the basis for the successful development of agriculture complex and ecosystem conservation. Materials of the International scientific and practical conference (2012)

12. E. Ganebnykh, T. Burtseva, N. Mironova, O. Feoktistova, E3S Web of Conferences 110, 01077 (2019) DOI: 10.1051/e3sconf /201911001077

13. E. Ganebnykh, T. Burtseva, A. Petukhova, A. Mottaeva, E3S Web of Conferences 91, 08035 (2019) DOI: 10.1051/e3sconf /201991080 